\title{
REMOVAL OF POTENTIALLY TOXIC METALS FROM AQUEOUS SOLUTION USING TETRA PAK INDUSTRIAL WASTE AS BIOSORBENTS
}

\author{
A. Muhammadi ${ }^{*}$, A.H. Lahori ${ }^{2}$, V. Vambol ${ }^{3}$, S. Vambol ${ }^{4}$ \\ ${ }^{1}$ Federal Urdu University of Arts, Science \& Technology Karachi, Karachi, Pakistan \\ ${ }^{2}$ Sindh Madressatul Islam University, Karachi, Pakistan \\ ${ }^{3}$ National University "Yuri Kondratyuk Poltava Polytechnic", Poltava, Ukraine \\ ${ }^{4}$ State Biotechnological University, Kharkiv, Ukraine \\ *Corresponding email: aqsa.env@gmail.com
}

Received: 12 August 2021; Accepted: 05 September 2021

Cite as: Muhammadi, A., Lahori, A.H., Vambol, V., Vambol, S. (2021). Removal of potentially toxic metals from aqueous solution using tetra pak industrial waste as biosorbents. Labour Protection Problems in Ukraine, 37(3), 3-7.

Potentially toxic metals (PTMs) contamination in the water bodies had been a worldwide challenge. Industrialization and anthropogenic activities have produce and discharge wastes comprising organic and inorganic pollutants into the water resources making them hazardous and threatening human health and the environment. Packaging technology for food and beverages such as juices, milk, and other liquids using paper packets, generally known as Tetra Pak, has resulted in the generation of too much waste in the world in recent decades. On the one hand, it appears that the building of composites from Tetra Pak trash allows for maximum recycling of these materials, while on the other hand, the inclusion of Kraft paper, $\mathrm{Al}$, and polyethylene in the packet composition can improve the functional features of the goods. Tetra pak packaging is comprised of three different types of raw materials: cellulose $(75 \%)$, low density polyethylene (LDPE) $(20 \%)$, and aluminium $(5 \%)$. The present research aimed to assess the potential of Tetra Pak industrial waste as biosorbents to remove PTMs such as lead $(\mathrm{Pb})$, Nickle (Ni), and Copper $(\mathrm{Cu})$ from PTMs-artificial contaminated water. Approximately, $0.05 \mathrm{mg} / \mathrm{L}$ concentration for $\mathrm{Ni}, 0.027 \mathrm{mg} / \mathrm{L}$ for $\mathrm{Pb}$, and $0.05 \mathrm{mg} / \mathrm{L}$ for $\mathrm{Cu}$ were artificially added in the water bodied to assess the adsorption efficacy amended with two samples of waste Tetra Pak OTP (sample product1) and DOTP (sample product 2) as biosorbents. The obtained results showed that the maximum $\mathrm{Ni}$ adsorption recovery was received by (83\% with DOTP), Pb $52 \%$ with OTP and $\mathrm{Cu} 32 \%$ with OTP as bio-sorbent amendments. Overall, the present study indicated that the remove of PTMs from dilute aqueous solutions and using industrial waste material as easily available and low-cost sorbent, that can be successfully used to remove pollutants from multi-metal polluted water. Keywords: adsorption; tetra pack; potentially toxic metals; polluted water.

\section{ВИДАЛЕННЯ ПОТЕНЦІЙНО ТОКСИЧНИХ МЕТАЛІВ ІЗ ВОДОЙМ З ВИКОРИСТАННЯМ ПРОМИСЛОВИХ ВІДХОДІВ ТЕТRА РАК ЯК БІОСОРБЕНТУ}

\author{
А. Мухаммаді ${ }^{*}$, А. Г. Лагорі ${ }^{2}$, В. Вамболь ${ }^{3}$, С. Вамболь ${ }^{4}$ \\ ${ }^{1}$ Федеральний університет мистецтв, науки і технологій урду, Карачі, Пакистан \\ ${ }^{2}$ Університет Сінд Мадрессатул Айлама, Карачі, Пакистан \\ ${ }^{3}$ Національний університет "Полтавська політехніка імені Юрія Кондратюка", Полтава, Україна \\ ${ }^{4}$ Державний біотехнологічний університет, Харків, Україна \\ *E-mail для листування: aqsa.env@gmail.com \\ Отримано: 12 Серпня 2021; Прийнято: 05 Вересня 2021
}

Цитувати як: Мухаммаді А., Лагорі А. Г., Вамболь В., Вамболь С. (2021). Видалення потенційно токсичних металів із водного розчину з використанням промислових відходів Tetra Pak як біосорбенту. Проблеми охорони праці в Украӥні, 37(3), 3-7.

\begin{abstract}
Забруднення водойм потенційно токсичними металами (ПТМ) стало проблемою в усьому світі. Індустріалізація та антропогенна діяльність призводять до утворення і скидання відходів, що містять органічні та неорганічні забруднювачі, в водні ресурси, що робить їх небезпечними і загрожують здоров'ю людини і навколишньому середовищу. Технологія упаковки харчових продуктів і напоїв, таких як соки, молоко та інші рідини, з використанням паперових пакетів, зазвичай відома як Теtra Раk, привела до утворення занадто великої кількості відходів в останні десятиліття. 3 одного боку, здається, що створення композитів зі сміття Теtra Рак дозволяє максимально переробити ці матеріали, а з іншого, - включення крафт-паперу, алюмінію та поліетилену до складу пакета може поліпшити функціональні характеристики упаковки. Упаковка Tetra pak складається $з$ трьох різних типів сировини: целюлози (75\%), поліетилену низької щільності (LDPE) (20\%) і алюмінію (5\%). Це дослідження спрямоване на оцінку потенціалу промислових відходів Теtra Рак в якості біосорбентів для видалення ПТМ, таких як свинець $(\mathrm{Pb})$, нікель $(\mathrm{Ni})$ і мідь $(\mathrm{Cu})$ з штучно забрудненій цими металами води. Приблизно 0,05 мг/л концентрації $\mathrm{Ni}, 0,027$ мг / л Pb i 0,05 мг / л Сu були штучно додані в водойму для оцінки адсорбційної ефективності 3 поправкою на два зразка відходів Tetra Pak OTP (зразок продукту 1) i Tetra Pak (DOTP) (зразок продукту 2) в якості біосорбентів. Отримані результати показали, що максимальне відновлення адсорбції Ni було отримано (83\% з DOTP), Pb 52\% 3 OTP і Сu 32\% з ОTР як добавки біосорбенту. В цілому, даний дослідження показало, що видалення ПТМ з розбавлених водних розчинів шляхом використання промислових відходів в якості доступного і недорогого сорбенту, може бути досить ефективним.
\end{abstract}

Ключові слова: адсорбція; Tetra pak; потенциально токсичні метали; забруднена вода.

1. Problem statement and analysis of the recent researches and publications.

With the world's population quickly rising and water supplies becoming scarcer, there is a pressing need to examine our consumption patterns and how we use our water resources. Potentially toxic metal (PTMs) contamination of the environment from industrial effluent is a big issue [1].
Metal ions are a severe environmental pollutant seen in industrial wastewater regularly [2]. It is eminent that about 70 to $80 \%$ of diseases in un-developed countries are because of the utilization of polluted water [3]. Because of their toxicity, persistence, and bioaccumulation in food chains, an increased release of PTMs into the aquatic environment creates major water pollution problems. Metals and pesticides, in particular, 
tend to collect and get magnified in the food chain. It is therefore necessary to inspect metals at the point of discharge to ensure that they do not enter the aqueous system [4]. To de-polluted water contaminated with PTMs, a variety of physicochemical methods are utilized around the world. These solutions, on the other hand, are fundamentally difficult to apply and are not cost-effective [5]. Biological processes such as bioaccumulation and biosorption have gotten a lot of attention recently due to a variety of benefits, and experts from all around the world have been working to determine the most effective biomass type [6]. Pakistan has a coastline of around 990 kilometers. Out of this, $960 \mathrm{~km}$ is largely pollution-free, whereas $30 \mathrm{~km}$ of Karachi's coastal water is heavily polluted from both home and industrial sources. According to a JICA report, about $20 \%$ of the city's annual wastewater is treated, while the rest is dumped untreated into Karachi Harbour and the surrounding coastal areas via the Lyari and Malir river outfalls. Different industrial units operate in the city are discharging their waste into coastal water [7]. Packaging technology for food and beverages such as juices, milk, and other liquids using paper packets, generally known as Tetra Pak, has resulted in the generation of too much waste in the world in recent decades. Around 312,000 tonnes of these items were found among Europe's 12 billion tonnes of recycled materials in 2006. On the one hand, it appears that the building of composites from Tetra Pak trash allows for maximum recycling of these materials, while on the other hand, the inclusion of Kraft paper, $\mathrm{Al}$, and polyethylene in the packet composition can improve the functional features of the goods [8].

The word "biosorption" refers to the non-metabolically mediated passive adsorption of metals to living or dead biomass. Because most current methods are ineffective and expensive, particularly when employed to reduce heavy metal ions to low concentrations, novel separation methods are needed to reduce heavy metal concentrations to environmentally acceptable levels at a reasonable cost. Various researchers have investigated a variety of low-cost biomass for mitigating pollution from various sources in various parts of the world. The majority of cellulosic materials tested were shown to be effective heavy metal adsorbents [9]. Traditional methods for the elimination of PTMs ions such as chemical precipitation and membrane filtration are too much expensive when amending at the huge amount of water, useless at low amounts of PTM (incomplete metal elimination) and produce large proportions of sludge and other toxic materials that require careful disposal. Biosorption and bio-accumulation are ecological alternatives. These alternative methods have merits over conservative method [10].The most abundant biopolymer in nature is cellulose. It is made up of glucose units that are linked together by b-1, 4-glycosidic linkages. The topics covered include washing, drying, and screening processes, as well as chemical treatments such as acid-base treatment and formaldehyde treatment. Although, phosphoration, carboxylation, sulfoethylation, carboxymethylation, and other chemical reactions [11].

The use of paper sludge as an adsorbent raw material has several benefits, including lowering the amount of solid waste produced and the cost of treatment, as well as offering a low-cost adsorbent for heavy metal removal. Because of their high carbon content and cellulose fibber proportion, paper sludge and other organic waste materials from the paper industry could be considered adsorbent materials [12]. A ton of pulp made from recycled paper uses $60 \%$ less energy to create than a ton of bleached virgin kraft pulp. PTMs have been dumped in huge quantities in the environment in recent years. Numerous techniques for metal removal from contaminated waters have been developed due to their toxicity [13].

Tetra Pak is a beverage and liquid food system that is commonly used as an aseptic packaging material around the world. This unique packaging technology allows products that were traditionally deemed perishable to be delivered and stored for up to six months or longer without refrigeration - even delicate foods like milk, soy drinks, juice, and nectars. More than 137 billion tetra pak packets were sent around the world in 2007. As a result, the number of trash tetra pak packaging in municipal solid wastes is steadily increasing. That is why, both economically and environmentally, converting discarded tetra pak packages into valuable chemicals or fuels is critical. Tetra pak packaging is made up of three primary materials: duplex paper about $75 \%, \mathrm{Al} 5 \%$, and low-density polyethylene $20 \%$. Three methods are used to recover the $\mathrm{Al}$ and polyethylene layers such as energy generation through incineration, aluminum recovery in pyrolysis ovens, and high-end plastic lumber goods are made by processing a blend of plastic and metal [14]. Therefore, the main aim of present research was to explore the potential of olpers tetra pack (OTP) and dairy omeng tetra pack (DOTP) industrial waste as biosorbents to eliminate PTMs such as lead $(\mathrm{Pb})$, Nickle $(\mathrm{Ni})$ and Copper $(\mathrm{Cu})$ from PTMs-artificial contaminated water. It is hypothesised that the tetra pak industrial waste as biosorbents might be highly effective to eliminate $\mathrm{Pb}, \mathrm{Ni}$, and $\mathrm{Cu}$ from metalpolluted water.

\section{Statement of the problem and its solution.}

2.1 Materials and methods.

Tetra Pak is made up of $25 \%$ LDPE, $70 \%$ kraft paper, and $5 \%$ aluminium, all of which are laminated in six layers. The tetra pak was stripped of its (Al) foil and plastic, leaving the only paper for the experiment. The paper pulp was washed many times with distilled water until the $\mathrm{pH}$ of the supernatant water layer of the pulp was around 6.5 to 7.0, to remove external contaminants such as oil, black ink, and bleaching agent (chlorine dioxide). To penetrate the phosphate into the cellulose matrix, the paper pulp was refluxed with 5.0 percent $\mathrm{Na} 2 \mathrm{HPO} 4$ for 3 hours using a water condenser. The analysis was carried out on three metals such as, $\mathrm{Ni}, \mathrm{Pb}$ and $\mathrm{Cu}$.

Lead. $1 \mathrm{~g}-5 \mathrm{~g}$ of lead nitrate salt was dissolved in $50 \mathrm{ml}$ of water to make a lead stock solution. In $0.5 \mathrm{~g}$ of sample, $50 \mathrm{ml}$ of each stock standard solution was introduced and allowed overnight for adsorption. The sample was filtered and dried before being used. $50 \mathrm{~mL}$ of each sample (filtrate) was placed in a volumetric flask with $2 \mathrm{~mL}$ of acetic acid and heated on a hot plate, followed by the addition of potassium dichromate to generate a yellow precipitate of lead chromate. The precipitates were weighed after being dried, filtered, and weighed again. $5 \mathrm{~mL}$ nitric acid $\left(\mathrm{HNO}_{3}\right)$, and $10 \mathrm{~mL}$ chloric acid $\left(\mathrm{HCLO}_{3}\right)$ was added to the paper sample and cooked on a hot plate until a clear solution was formed. The final volume was made up to $50 \mathrm{ml}$, then $2 \mathrm{ml}$ of acetic acid was added, the solution was heated on a hot plate again, cooled, and potassium dichromate was added to create the precipitate. Adsorbed lead was found in the precipitates.

Nickel. Nickel chloride salt stock standard solutions were made with concentrations ranging from $0.01 \mathrm{M}$ to $0.05 \mathrm{M} .50 \mathrm{ml}$ of each stock standard solution was added to $0.5 \mathrm{~g}$ of sample and left overnight for adsorption. The sample was filtered and dried before being used. In a volumetric flask, $50 \mathrm{ml}$ of the 
sample (filtrate) was placed and heated to 75 degrees Celsius. $5 \mathrm{~mL}$ ammonia was added, then $35 \mathrm{~mL}$ DMG was added, and it was placed on a water bath for 15 minutes, after which the precipitate was filtered, dried, and weighed. $5 \mathrm{~mL}$ nitric acid and $10 \mathrm{~mL}$ chloric acid was added to the paper sample and cooked on a hot plate until a clear solution was formed. The final amount was made up to $50 \mathrm{ml}$, with $10 \mathrm{ml}$ of ammonia and DMG added before being placed in a water bath. Filtered, dried, and weighed precipitates.

Copper. To begin, prepare a copper chloride standard in $250 \mathrm{~mL}$ with a concentration range of $0.01-0.05 \mathrm{M}$. In $0.5 \mathrm{~g}$ of sample, $50 \mathrm{ml}$ of each stock standard solution was introduced and allowed overnight for adsorption. Filtration and drying were done on the sample. The sample was filtered next day, and the solution was made up to $20 \mathrm{ml}$ with $1 \mathrm{ml}$ $\mathrm{NH}_{4} \mathrm{OH}$, and the absorbance was measured with a spectrophotometer at $610 \mathrm{~nm}$. Digestion of paper was done with $1 \mathrm{~mL}$ nitric acid $\left(\mathrm{HNO}_{3}\right)$ and $1 \mathrm{~mL}$ chloric acid $\left(\mathrm{HCLO}_{3}\right)$, boiled on a hot plate till $1 \mathrm{~mL} \mathrm{NH}_{4} \mathrm{OH}$ was added, and makeup to the mark $50 \mathrm{~mL}$ with distilled water, and absorbance was measured at $610 \mathrm{~nm}$ with a spectrophotometer.

Statistical analysis. The data were analysed using Excel 2013 and the graphs were made by using OriginPro software (version 16).

\subsection{Results and Discussion.}

\subsubsection{Sample characterization}

Three main components are grouped in six layers in Tetra pak packaging materials: duplex paper cellulose fibres $75 \%$, low-density polyethylene (LDPE) $20 \%$, and aluminium (Al) $5 \%$. Cellulosic fibres make up the majority of Tetra pak panels, accounting for $75 \%$, and LDPE, a thermoplastic substance, makes up the remaining $20 \%$. Al, which is a metal, is the third component. Even though it is widely known that cellulose fibres make about $75 \%$ of the material, it is not pure cellulose. The kraft process, often called as kraft pulping, is a chemical process that produces the paper used in Tetra pak packaging material. The kraft method is thought to remove more than 95 percent of the lignin in wood. There are still some polyoses like xylose and mannose, as well as some lignin, after the kraft process [15]. The illustrated chemical characteristics of tetra pack packaging material are indicated in (Figure 1).

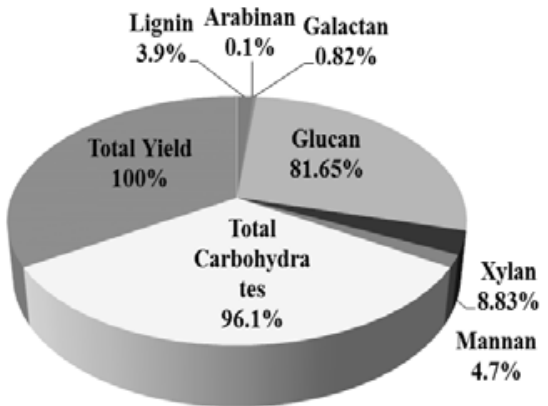

Chemical properties of tetra pak packaging material

Figure 1 - Paper used in tetra pak packaging material chemical characterization [15]

\subsubsection{Impact of absorbents on adsorption of potentially} toxic metals in water

The initial concentration acts as a powerful driving force, overcoming all adsorbed mass transfer resistance between the aqueous and solid phases [16]. As shown in (Figure $2 \mathrm{a}, \mathrm{b}, \mathrm{c}$ ), the maximum adsorption capacity of $\mathrm{Ni}$ in the artificial contaminated water was observed by $0.12 \mathrm{mg} / \mathrm{g}$ with application of DOTP as compared with OTP. Because, oxygen-containing cellulose has a higher attractive force, this occurs. Furthermore, greatest the adsorption potential of $\mathrm{Pb}$ was noted by 0.000995 $\mathrm{mg} / \mathrm{g}$ in artificial contaminated water with application of OTP rather the DOTP. Similarly, the highest adsorption capability of $\mathrm{Pb}$ in artificial polluted water was found by $0.01003 \mathrm{mg} / \mathrm{g}$ amended with OTP as compared with DOPT. It was assumed that that DOTP as bio-sorbent has potential to adsorb mo Ni in the water bodies, whereas OTP has capability to adsorbed maximum $\mathrm{Cu}$ and $\mathrm{Pb}$ in the contaminated water, mean while it could might be due to nature and chemical properties of potentially toxic metals in the water bodies.
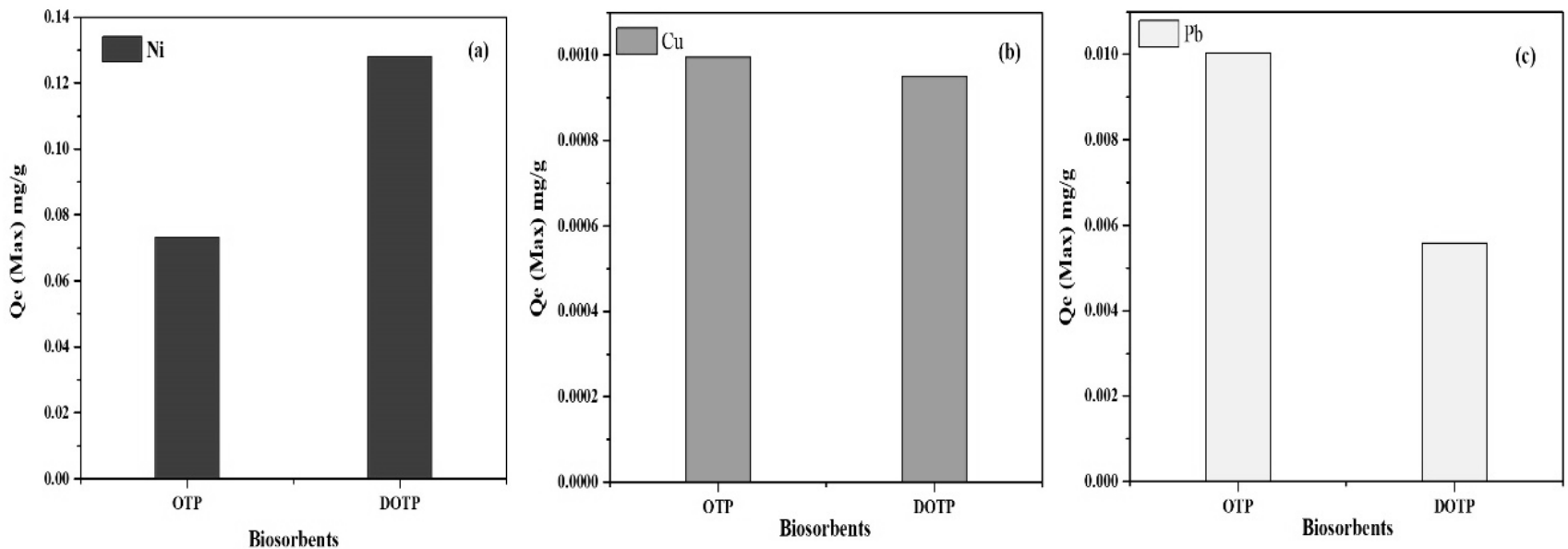

Figure 2 - Adsorption capacity of $\mathrm{Ni}(\mathrm{a}), \mathrm{Cu}(\mathrm{b})$ and $\mathrm{Pb}(\mathrm{c})$ in water with application of OPT and DOTP

\subsubsection{Recovery of potentially toxic metals in artificial} contaminated water

The maximum $\mathrm{Ni}$ adsorption recovery in the water body was received by $83 \%$ with application DOTP as compared with OTP. While, in case of $\mathrm{Pb}$ content in the water body the maximum recovery was observed by $52 \%$ with application of OTP rather than DOTP. Likewise, the greatest recovery of $\mathrm{Cu}$ in the water bodies was received by $32 \%$ with application of OTP as compared with DOTP (Figure 3). It is observed that the DOTP has potential to easily recovered $\mathrm{Ni}$ from water bodies 
as compared with $\mathrm{Pb}$ and/or $\mathrm{Cu}$. However, OPT as additive was found to be highly effective to recover $\mathrm{Pb}$ and $\mathrm{Cu}$ from aqueous solution as compared with $\mathrm{Ni}$. This recovered metal may be recycled in other processes, making it a very costeffective commercialization method for any sector. Singh and Ali [3] reported that $\mathrm{Cu}^{2}+, \mathrm{Pb}^{2}+$ and $\mathrm{Ni}^{2}+$ were evidently removed from industrial effluents with application of agricultural wastes made biosorbent. Khan et al. [17] stated that the removal capacity of $\mathrm{Ni}^{2}+$ and $\mathrm{Cu}^{2}+$ in the aqueous solution was observed by $90 \%$ with application of biomass and clay materials. Shin [18] revealed that the adsorption of $\mathrm{Ni}^{2}+, \mathrm{Cu}^{2}+$ and $\mathrm{Pb}^{2}+$ in the waste water treatment system was observed with application of Hizikia fusiformis made biochar.

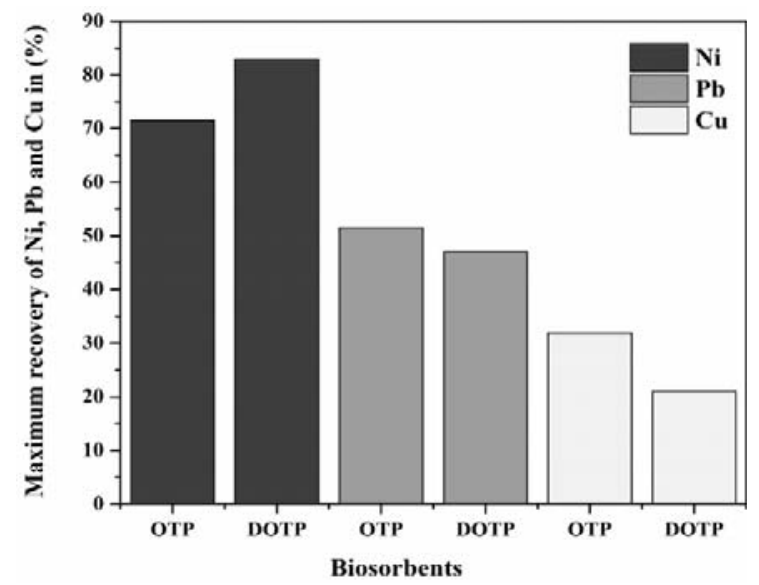

Figure 3 - Maximum recovery of potentially toxic metals in water

\section{Conclusion.}

A bio-sorption technique that can successfully applied the living or dead biomass to eliminate the potentially toxic metals viz., $\mathrm{Ni}, \mathrm{Pb}$ and $\mathrm{Cu}$ from polluted water. The waste products from the Tetra pak industry seemed to be sufficient for recovery of $\mathrm{Ni}, \mathrm{Pb}$ and $\mathrm{Cu}$ in the water bodies. The use of tetra pak to $\mathrm{Ni}, \mathrm{Pb}$ and $\mathrm{Cu}$ from industrial water was revealed in this study. In the present work DOPT has potential to recover Ni in the water bodies, whereas OTP was found to be highly effective for recover of $\mathrm{Pb}$ and $\mathrm{Cu}$ from artificially potential toxic metal polluted water. Gravimetric, traditional digestion, and spectrophotometer methods are used in the research. The pattern of $\mathrm{Ni}, \mathrm{Pb}$ and $\mathrm{Cu}$ removal can be better understood by comparing multiple samples from the same category. Due to the use of traditional methods, there was an error in the expected outcome, and it was difficult to analyse all areas using the same way. Future studies must be focused on conversion of tetra pack waste material to prepare biochar at low or fast pyrolysis temperature for stabilization of pollutant from multimetal polluted water and soil.

\section{Funding}

This research work did not receive any specific funding from any institute or organization.

\section{Acknowledgements.}

We are gratefully acknowledged to Federal Urdu University of Arts, Science \& Technology Karachi.

\section{Conflict of interest}

The author declares no any conflict of interest exists in the submission of this research paper.

\section{REFERENCES}

1. Volesky, B. (2003). Biosorption process simulation tools. Hydrometallurgy, 71(1-2), 179-190.

2. Klimmek, S., Stan, H. J., Wilke, A., Bunke, G., Buchholz, R. (2001). Comparative analysis of the biosorption of cadmium, lead, nickel, and zinc by algae. Environmental science \& technology, 35(21), 4283-4288

3. Singh, J., Ali, A.G. (2013). Agricultural Wastes as Adsorbents for the Removal of Toxic Metal Ions from Industrial Effluents (Doctoral dissertation)

4. Klavins, M., Potapovics, O., Rodinov, V. (2009). Heavy metals in fish from lakes in Latvia: concentrations and trends of changes. Bulletin of environmental contamination and toxicology, 82(1), 96-100.

5. Volesky, B. (2001). Detoxification of metal-bearing effluents: biosorption for the next century. Hydrometallurgy, 59(2-3), $203-216$.

6. Hadiani, M.R., Darani, K. K., Rahimifard, N., Younesi, H. (2018). Biosorption of low concentration levels of Lead (II) and Cadmium (II) from aqueous solution by Saccharomyces cerevisiae: Response surface methodology. Biocatalysis and agricultural biotechnology, 15, 25-34.

7. Jilani, S. (2015). Assessment of heavy metal pollution in Lyari river and adjoining coastal areas of Karachi. Journal of Biodiversity and Environmental Sciences, 6(2), 208-214

8. Ebadi, M., Farsi, M., Narchin, P. (2018). Some of the physical and mechanical properties of composites made from Tetra $\mathrm{Pak}^{\mathrm{TM}}$ /LDPE. Journal of Thermoplastic Composite Materials, 31(8), 1054-1065.

9. Suryan, S., Ahluwalia, S.S. (2012). Biosorption of heavy metals by paper mill waste from aqueous solution. International Journal of Environmental Sciences, 2(3), 1331

10. Kanamarlapudi, S.L.R.K., Chintalpudi, V.K., Muddada, S. (2018). Application of biosorption for removal of heavy metals from wastewater. Biosorption, 18, 69. 70-116. DOI: 10.5772/intechopen.77315

11. Chakravarty, S., Bhattacharjee, S., Gupta, K.K., Singh, M., Chaturvedi, H.T., Maity, S. (2007). Adsorption of zinc from aqueous solution using chemically treated newspaper pulp. Bioresource technology, 98(16), 3136-3141.

12. Siswoyo, E., Tanaka, S. (2013). Development of eco-adsorbent based on solid waste of paper industry to adsorb cadmium ion in water Journal of Clean Energy Technologies, 1(3), 198-201.

13. Méndez, A., Barriga, S., Fidalgo, J.M., Gascó, G. (2009). Adsorbent materials from paper industry waste materials and their use in Cu (II) removal from water. Journal of Hazardous Materials, 165(1-3), 736-743.

14. Korkmaz, A., Yanik, J., Brebu, M., Vasile, C. (2009). Pyrolysis of the tetra pak. Waste management, 29 (11), 2836-2841.

15. Yilgor, N., Köse, C., Terzi, E., Figen, A. K., Ibach, R., Kartal, S. N., Pişkin, S. (2014). Degradation behavior and accelerated weathering of

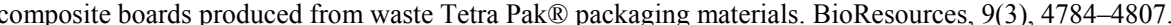

16. Allen, S. J., Gan, Q., Matthews, R., Johnson, P.A. (2005). Mass transfer processes in the adsorption of basic dyes by peanut hulls. Industrial \& engineering chemistry research, 44(6), 1942-1949.

17. Khan, A. M., Ahmad, C. S., Farooq, U., Mahmood, K., Sarfraz, M., Balkhair, K. S., Ashraf, M. A. (2015). Removal of metallic elements from industrial waste water through biomass and clay. Frontiers in Life Science, 8(3), 223-230.

18. Shin, W.S. (2017). Adsorption characteristics of phenol and heavy metals on biochar from Hizikia fusiformis. Environmental earth sciences, $76(22), 782$

Мухаммади А., Лагори А. Г., Вамболь В., Вамболь С

УДАЛЕНИЕ ПОТЕНЦИАЛЬНО ТОКСИЧНЫХ МЕТАЛЛОВ ИЗ ВОДОЕМОВ С ИСПОЛЬЗОВАНИЕМ ПРОМЫШЛЕННЫХ ОТХОДОВ ТЕТRА РАК В КАЧЕСТВЕ БИОСОРБЕНТОВ 
Загрязнение водоемов потенциально токсичными металлами (ПТМ) стало проблемой во всем мире. Индустриализация и антропогенная деятельность приводят к образованию и сбросу отходов, содержащих органические и неорганические загрязнители, в водные ресурсы, что делает их опасными и угрожающими здоровью человека и окружающей среде. Технология упаковки пищевых продуктов и напитков, таких как соки, молоко и другие жидкости, с использованием бумажных пакетов, обычно известная как Tetra Pak, привела к образованию слишком большого количества отходов в последние десятилетия. С одной стороны, кажется, что создание композитов из мусора Tetra Pak позволяет максимально переработать эти материалы, а с другой, - включение крафт-бумаги, алюминия и полиэтилена в состав пакета может улучшить функциональные характеристики упаковки. Упаковка Tetra pak состоит из трех различных типов сырья: целлюлозы (75 \%), полиэтилена низкой плотности (LDPE) (20\%) и алюминия (5\%). Настоящее исследование направлено на оценку потенциала промышленных отходов Tetra Pak в качестве биосорбентов для удаления ПТМ, таких как свинец (Pb), никель (Ni) и медь $(\mathrm{Cu})$ из искусственно загрязненной этими металлами воды. Приблизительно 0,05 мг/л концентрации $\mathrm{Ni}$, $0,027 \mathrm{мг} / л \mathrm{~Pb}$ и 0,05 мг/л $\mathrm{Cu}$ были искусственно добавлены в водоем для оценки адсорбционной эффективности с поправкой на два образца отходов Tetra Pak OTP (образец продукта 1) и Tetra Pak (DOTP) (образец продукта 2) в качестве биосорбентов. Полученные результаты показали, что максимальное восстановление адсорбции Ni было получено (83 \% c DOTP), Pb 52 \% с ОТР и Сu 32 \% с ОТР в качестве добавок биосорбента. В целом, настоящее исследование показало, что удаление ПТМ из разбавленных водных растворов путем использования промышленных отходов в качестве легкодоступного и недорогого сорбента, может быть достаточно эффективным.

Ключевые слова: адсорбция; Tetra pak; потенциально токсичные металлы; загрязненная вода. 